\title{
BANGER WATERSHED MANAGEMENT IN SEMARANG CITY
}

\author{
Ikhwanudin* \\ Ph.D Candidate, Universitas Islam Sultan Agung Semarang, \\ Jalan Raya Kaligawe, Central Java 50112, Indonesia \\ S I Wahyudi, Soedarsono \\ Civil Engineering Departement, Universitas Islam Sultan Agung, \\ Jalan Raya Kaligawe, Central Java 50112, Indonesia \\ *Corresponding Author: ikhwan.menur12@gmail.com
}

\begin{abstract}
Floods that occur on the north coast of Central Java in general are caused by high rainfall, where water flows from upstream to downstream carrying soil grain and rubbish in the form of used bottles, plastic, tree branches and others so that the presence of waste will disrupt and inhibit the flow rate of water. Government efforts to deal with flooding in the city of Semarang by optimizing the retention pool in the city of Semarang for example retention ponds in Tawang, Muktiharjo, Tanah Mas and Banger, these pools are used to collect water and later the water will be discharged using a pump to the river then to the sea, if there is a tide or tidal flood that inundates the streets and houses, the pump is turned on. Meanwhile, if the water recedes and does not inundate residential areas, the pump is turned off. The purpose of this study is to formulate a correlation between pumps and retention ponds, while flood control uses a 50 year return count Banger watershed flood control uses a $3 \mathrm{~m}$ deep pond pool volume of 406,000 $\mathrm{m}^{3}$. The pump is set to start at 2.5 meters of water depth, and shut down at a depth of 0.5 meters.
\end{abstract}

Keywords: Longstrorage, Banger, Pump.

Cite this Article: Ikhwanudin, S I Wahyudi, Soedarsono, Banger Watershed Management in Semarang City. International Journal of Civil Engineering and Technology, 11(4), 2020, pp. 106-114.

https://iaeme.com/Home/issue/IJCIET?Volume=11\&Issue $=4$

\section{INTRODUCTION}

The city of Semarang often occurs floods during the rainy season, especially during high rainfall, in addition to high rainfall caused by sedimentation, siltation and damage to tertiary, secondary and primary channels including A2 channels so that during high rainfall the water will not be accommodated in the channel The existence of public awareness of environmental conditions is evident that there is a lot of garbage in A2 channels and Kali Banger. 
Government efforts to deal with flooding in the city of Semarang by optimizing the retention pool in the city of Semarang for example retention ponds in Tawang, Muktiharjo, Tanah Mas and Banger, these pools are used to collect water and later the water will be discharged using a pump to the river then to the sea, if there is a tide or tidal flood that inundates the streets and houses, the pump is turned on. Meanwhile, if the water recedes and does not inundate residential areas, the pump is turned off. To reduce the risk and number of flood events, a proper and integrated flood control system planning is needed, and in planning a flood control system is needed in an area with evaluation and analysis that takes into account flood inundation areas or their coverage. Flood characteristics in the form of a puddle area inundation depth, and water flow velocity need to be mapped so that it can be a strong basis in flood control planning. Kodoatie (2013). Efforts to prevent flooding in the city of Semarang basically have three approaches namely. a. Flood control coming from the watershed in Hulu, b. Local area flood control, and c. flood control is caused by rob. (1)

Flooding in the city of Semarang is caused by : a. the geographical conditions of the city of Semarang which has areas of potential flooding, because there are areas located in high areas and areas located in low-lying areas causing floods of shipments originating from the southern area of Semarang City and Semarang district. according to Pramono (2002) , b. a change in land use from rubber forests to housing in the Mijen district, c. the pressing of hills in several places results in changes in water flow patterns, erosion And the non-technical problem is the poor behavior of the people of Semarang. The behavior of people who do not care about environmental care such as throwing garbage in waterways and in random places and closing drainage channels to build street vendors become commonplace (2)

The level of influence of tidal elevation on the Rob Flood in the Kaligawe Semrang area. In no rain conditions the embankment elevation along the Kaligawe Road in Semarang can still accommodate and during daily rainfall conditions $>80 \mathrm{~mm}$ there will be inundation in the Semarang Kaligawe area (3)

There is also the cause of high tides and land subsidence (Land subsidence) are the main threats in the City of Semarang (5) (6) (4). Effect of Land Subsidence on Flooding and Rob in East Semarang Flood and tidal floods were analyzed with the help of GIS Arc by overlapping the DEM map of the flood water level with the DEM of the land surface. From the results of the analysis the rate of subsidence of land subsidence ranged from 0 in the southern region and increasingly north is getting bigger with the largest value reaching $-5.58 \mathrm{~cm} /$ year. Over a period of 17 years 2014-2031(7)

Climate change has resulted in changes in the characteristics of rain in the East Flood Canal River Basin,i.e. annual rainfall and maximum daily rainfall are likely to increase whereas the number of rainy days tends to decrease. Annual rainfall rises an average of 22.64 $\mathrm{mm} /$ year, while the maximum daily rainfall increased by an average of $2.56 \mathrm{~mm}$ / year, and the number of rainy days decreased by an average of 4 days /year. (7)(2)

The condition of land elevation which is lower than sea level will cause Rob Flooding in Semarang, resulting in damage to facilities and infrastructure both roads, housing, sanitation, and other infrastructure so that it affects the lives of people directly affected by tidal flooding.(8)

The drainage system is considered as an effective and efficient alternative to tackling the problem of floods and tides in the Tawang Sari and Tawang Mas areas which has a sloping topography Drainage system planning includes planning long storage, pump housing, dykes and floodgates. (1)(9) 


\section{METHODE OF RESEARCH}

The research method uses a qualitative method that is in accordance with conditions in the field. Which consists of: Rainfall Data, Topographic Data, Pool Area, Pool / Longstorage Capacity, Pump Capacity, Tidal Data, using references from the Maritime Rain Station in 2018. The analysis methods used are among other things:

\subsection{Hydrological Analysis}

Determine the rain station closest to the Banger watershed, namely the Tanjung Mas Maritime Rain Station, while the data used are rainfall data and catchment area. In the hydrological analysis will discuss the steps to determine the flood discharge plan. The steps to determine the flood discharge plan are to calculate regional average rainfall, plan rainfall, conduct alignment tests to determine methods that meet the distribution test, calculate rainfall intensity and plan flood discharge. Calculate Regional Average Rainfall Using the Thiessen Method

\subsection{Hydraulic Analysis}

To determine the potential for retention pool discharge which is calculated based on the difference between the return flood flood discharge and the discharge capacity of each river cross section (9)

\subsection{Flood Discharge Analysis Plan}

The depiction of the catchment area is done by dividing residential areas and roads that are adjusted to the drainage channel in the existing conditions. In addition, the depiction of the catchment area is also determined based on the direction of flow and elevation in the existing concession. According to Royna Kristian Yudi 92017)(10) The planning of this polder system includes planning of retention ponds, pumping stations, repairing rivers and sea dikes. Calculation of flood discharge using HEC-HMS 4.0 modeling. Planning for river improvement using HEC-RAS model 5.0.1. The sea dike is planned by considering the highest tides, wind and wave generation, sea level rise and land subsidence at the dike site. The retention pond has an area of 126 hectares with a depth of 3.4 meters and a 10-year flood plan for the pond is $126.6 \mathrm{~m} 3 / \mathrm{s}$. There are 4 pumps with a capacity of $15 \mathrm{~m} 3 / \mathrm{s}$ each. Discharge for each river is $82.3 \mathrm{~m} 3 / \mathrm{s}$ for the Tenggang River and $49.6 \mathrm{~m} 3 / \mathrm{s}$ for the Sungaiingin River. The embankment is at an elevation of +2.7 meters above sea level and is built from the East Flood Canal to the Babon River along the 1.73 kilometers

\section{RESULT AND DISCUSSION}

\subsection{Hydrological Analysis (Distribution of Rainfall in Watersheds)}

In general, hydrological analysis is one part of the initial analysis in the design of hydraulic buildings.) Hydrological analysis is used to obtain the amount of flood discharge plans in a plan. The steps to get the discharge plan are as follows: a.Determine the Watershed (DAS) along with its extent. b. Determine the area of influence of the rain stations. c. Determine the average daily maximum rainfall in the watershed from the existing rainfall data. d. Analyze rainfall plans with a $\mathrm{T}$ year return period. e. Calculates plan flood discharge based on plan rainfall over the $\mathrm{T}$ year return period.

Based on checking experiments on the 2 other closest stations, namely Karangroto and Pucanggading using the Thiessen method with the help of ArcGIS 10.5 software resulting division of sections and area of influence of rain stations on each section using the Thiessen method: (Ikhwanudin at.al, 2018) 


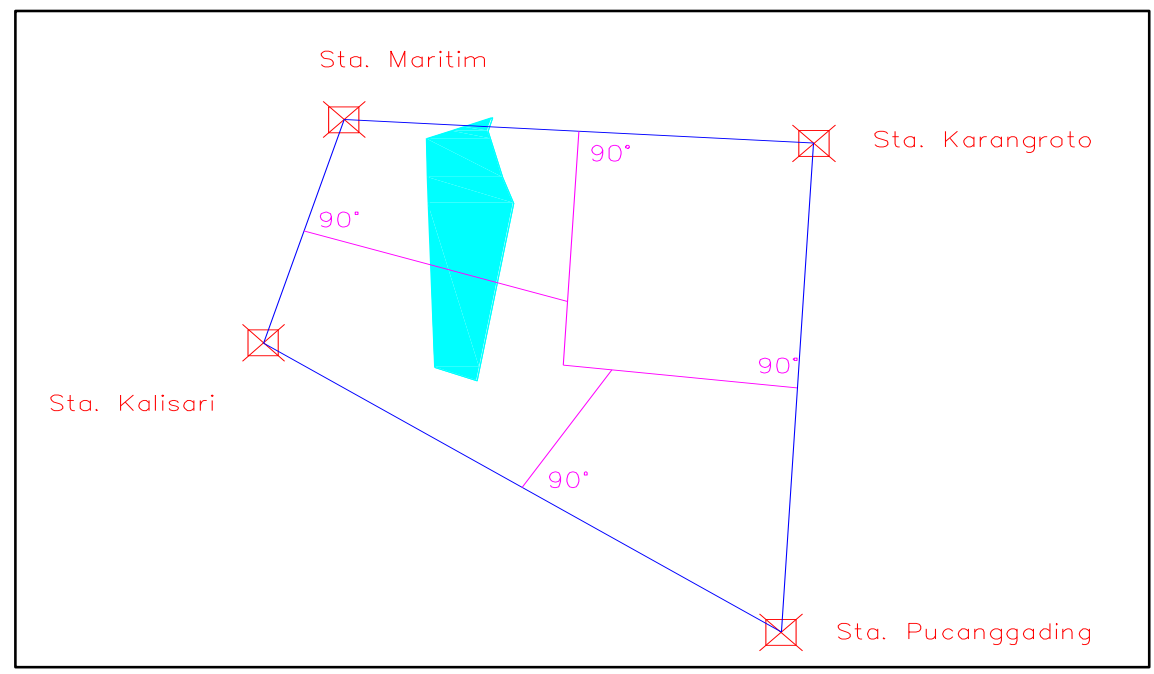

Figure 1 Cacthment Area DAS Banger

Based on the picture above, that the Banger Watershed Catchment Area is indeed only affected by the Maritime Rain Station. So the coefficient for the catchment area is as follows.

Table 1 Area of Effect of Rain Station on the Banger River Basin

\begin{tabular}{lcc}
\cline { 2 - 3 } & Luas Catchment Area $\left(\mathbf{m}^{2}\right)$ & Koefisien Thiessen \\
\cline { 2 - 3 } CA Maritim & $5,675,210$ & 1.00 \\
Luas DAS Banger & $5,675,210$ & 1.00 \\
\hline
\end{tabular}

Source: (Ikhwanudin at.al, 2018)

Table 2 Regional Maximum Rainfall at the Maritime Rain Station

\begin{tabular}{cccc}
\hline No & year & date & $\begin{array}{c}\text { Rainfall } \\
\text { Maximum }\end{array}$ \\
\hline 1 & 2009 & 25 Desember & 104,50 \\
2 & 2010 & 11 Desember & 168,60 \\
3 & 2011 & 2 Januari & 89,00 \\
4 & 2012 & 4 Februari & 96,00 \\
5 & 2013 & 23 Februari & 135,30 \\
6 & 2014 & 23 Januari & 120,50 \\
7 & 2015 & 13 Februari & 119,00 \\
8 & 2016 & 11 April & 74,00 \\
9 & 2017 & 28 Oktober & 99,50 \\
10 & 2018 & 17 Februari & 138,50 \\
\hline
\end{tabular}

Source: (Ikhwanudin at.al, 2018)

Rain Frequency Frequency analysis in this study uses A Prob software version 4.1 which was developed by Ir. Istiarto, M. Eng., Ph.D staff lecturer at Gajahmada University. Log Pearson III distribution distribution with the smallest maximum difference of 0.090. It was proven in Smirnov-Kolmogorof and Chi-Square test, the distribution of Pearson III Log data was passed. The magnitude of the rain return is as follows : 
Table 3 Banger River Basin Rainfall Based on Re-Period.

\begin{tabular}{cc}
\hline Kala Ulang & Log Pearson III \\
\hline 2 & 104 \\
5 & 131 \\
10 & 147 \\
20 & 163 \\
50 & 182 \\
100 & 196 \\
\hline
\end{tabular}

Source: (Ikhwanudin at.al, 2018)

The location of this research is in the Catchment Area (CA) of the Banger River Basin. Downstream areas have low and sloping topography. Where every sea experiences high tides this area is always submerged in water because the water enters through the Banger River which is connected to the East Flood Canal (KBT). Besides flooding is also caused because the available pumps have not been able to serve the flood discharge that comes when high rainfall. In the planning of the Banger drainage system, it is planned to use the Polder system, namely by utilizing the drainage channel to become a reservoir or so-called long storage.

\subsection{Alternative Storage Plan}

To cope with flooding in the Banger Catchment area, a drainage system plan in the area which consists of retention ponds, channels and pumps can be made can be seen in Figure 2

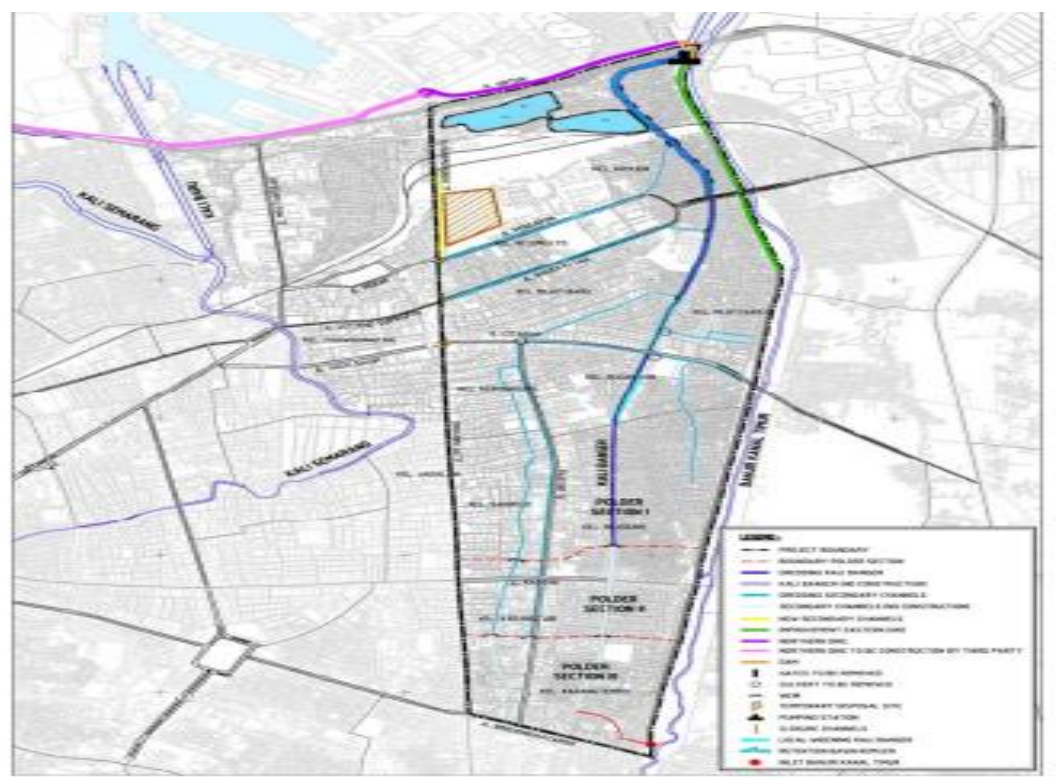

Figure 2 Alternative location plan for retention ponds (Ikhwanudin.at al., 2020)

The tables and characteristics of the pool of ponds that have been identified and which become the input database of the retention pool plan in this analysis are shown in the following tables: 
Table 4 Retention Pool

\begin{tabular}{ccccc}
\hline Depth $(\mathbf{m})$ & $\begin{array}{c}\text { Elevation } \\
(\mathbf{m})\end{array}$ & $\begin{array}{c}\text { Large } \\
\text { (ha) }\end{array}$ & $\begin{array}{c}\text { Volume } \\
\left(\mathbf{1 0 0 0} \mathbf{~ m}^{\mathbf{3}}\right)\end{array}$ & $\begin{array}{c}\text { Pool } \\
\text { Volume } \\
\left(\mathbf{1 0 0 0} \mathbf{~ m}^{\mathbf{3}}\right)\end{array}$ \\
\hline 3 & 2 & 13.54 & 135 & 406 \\
2 & 1 & 13.54 & 135 & 271 \\
1 & 0 & 13.54 & 135 & 135 \\
0 & -1 & 13.54 & 0 & 0 \\
\hline
\end{tabular}

The watershed reviewed in the calculation is the Banger watershed which is then divided into sub-watersheds. The depiction of the sub-watershed is done by dividing residential areas and roads that are adapted to drainage channels in existing conditions. In addition, the drawing of Sub Watersheds is also determined based on the direction of flow and elevation in the existing conditions. The polder system in the Banger Watershed is to analyze the capacity of the retention pond plan with pumps. The principle of analysis is that retention ponds are a function of pump capacity. The greater the retention pool storage, the smaller the pump capacity needed, and vice versa

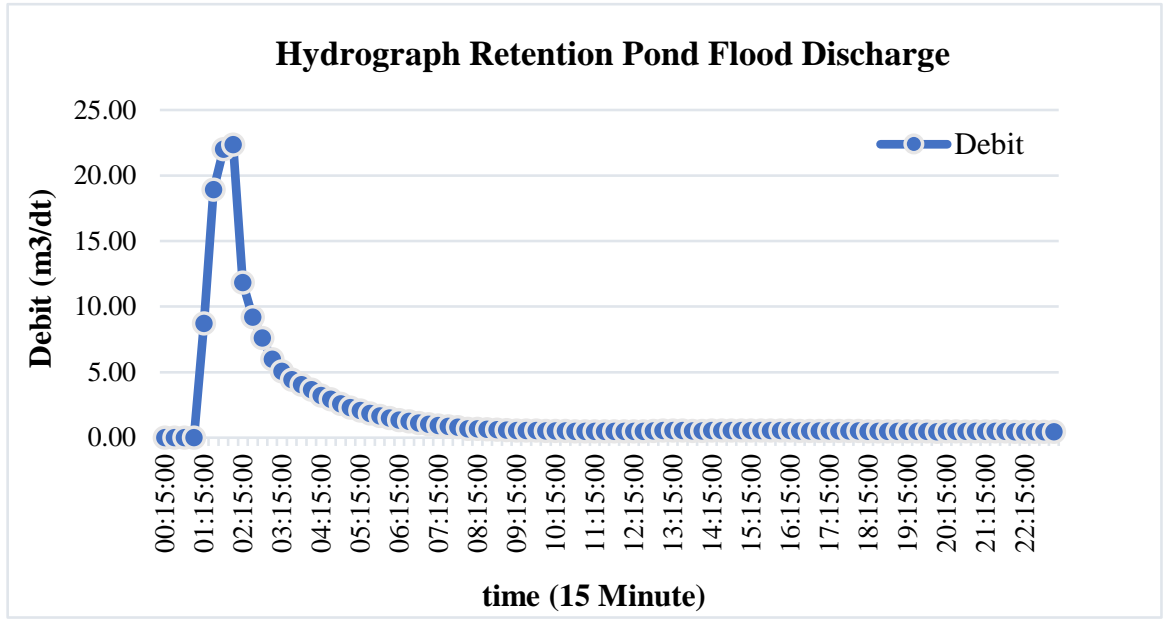

Figure 3 Hydrograph Retention Pond Flood Discharge (Ikhwanudin.at al., 2019)

With a retention pond area of 13.54 ha, the pool depth is $3.0 \mathrm{~m}$ and the storage volume is $406,000 \mathrm{~m}^{3}$. pump capacity of $5 \mathrm{~m}^{3} / \mathrm{s}$ The pump is set to start at a depth of 2.5 meters, and shut down at a depth of 0.5 meters. Pump capacity variations $3 \times 1.5 \mathrm{~m}^{3} / \mathrm{s}$ and $1 \times 0.5 \mathrm{~m}^{3} / \mathrm{sec}$, the pump operating schedule in Table 5. The pump is set to start at a depth of 2.5 meters, and shut down at a depth of 0.5 meters from the bottom of the pond. Assuming pond water depth is 2 meters at the time of pumping.

Table 5 Pump Operation Schedulle

\begin{tabular}{|c|c|c|}
\hline $\begin{array}{c}\text { Water depth } \\
(\mathbf{m})\end{array}$ & $\begin{array}{c}\text { Elevation } \\
(\mathbf{m})\end{array}$ & $\begin{array}{c}\text { Pump debit } \\
\left(\mathbf{m}^{3} / \mathbf{d t}\right)\end{array}$ \\
\hline 0 & $-2,7$ & 0 \\
\hline 0,5 & $-2,2$ & 1,5 \\
\hline 1 & $-1,7$ & 1,5 \\
\hline 1,5 & $-1,2$ & 3 \\
\hline 2 & $-0,7$ & 3 \\
\hline 2,5 & $-0,2$ & 4,5 \\
\hline \multicolumn{2}{|r}{} \\
\hline
\end{tabular}


As per the pump operating schedule, the depth of the pool is maintained so as not to overflow / puddle occurs. So that the depth of the pool is obtained as in Figure 4, where the surface of the pool water remains at a depth of $2.4 \mathrm{~m}$ and does not run off.

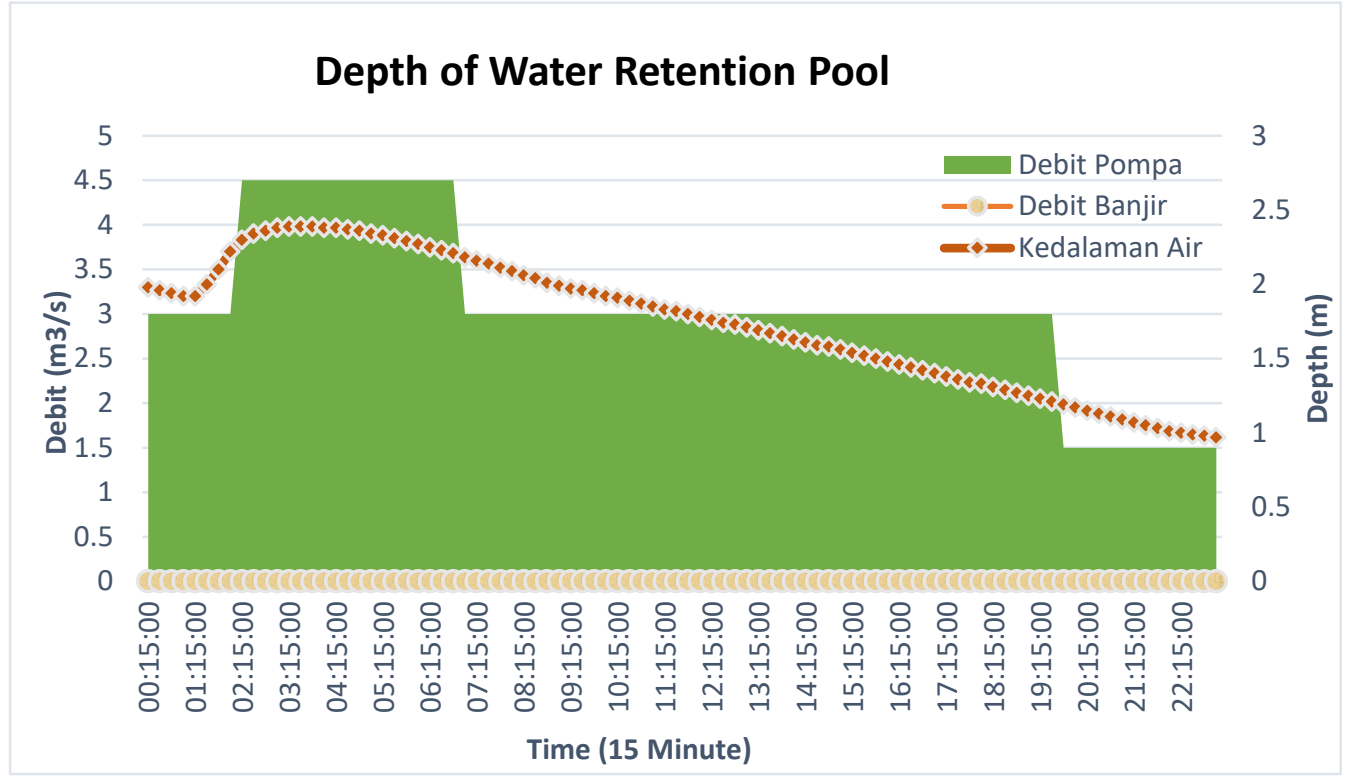

Figure 4. Depth of Water Retention Pool

The pump that is turned on varies at several depths of pond. At a pond depth of $0.5 \mathrm{~m}$, a pump with a capacity of $2 \mathrm{~m}^{3} / \mathrm{s}$ is started. At a depth of $4 \mathrm{~m}$ the pump capacity is increased to $2 \times 2 \mathrm{~m}^{3} / \mathrm{s}$, maintained until the water depth at the LS increases to $5 \mathrm{~m}$.

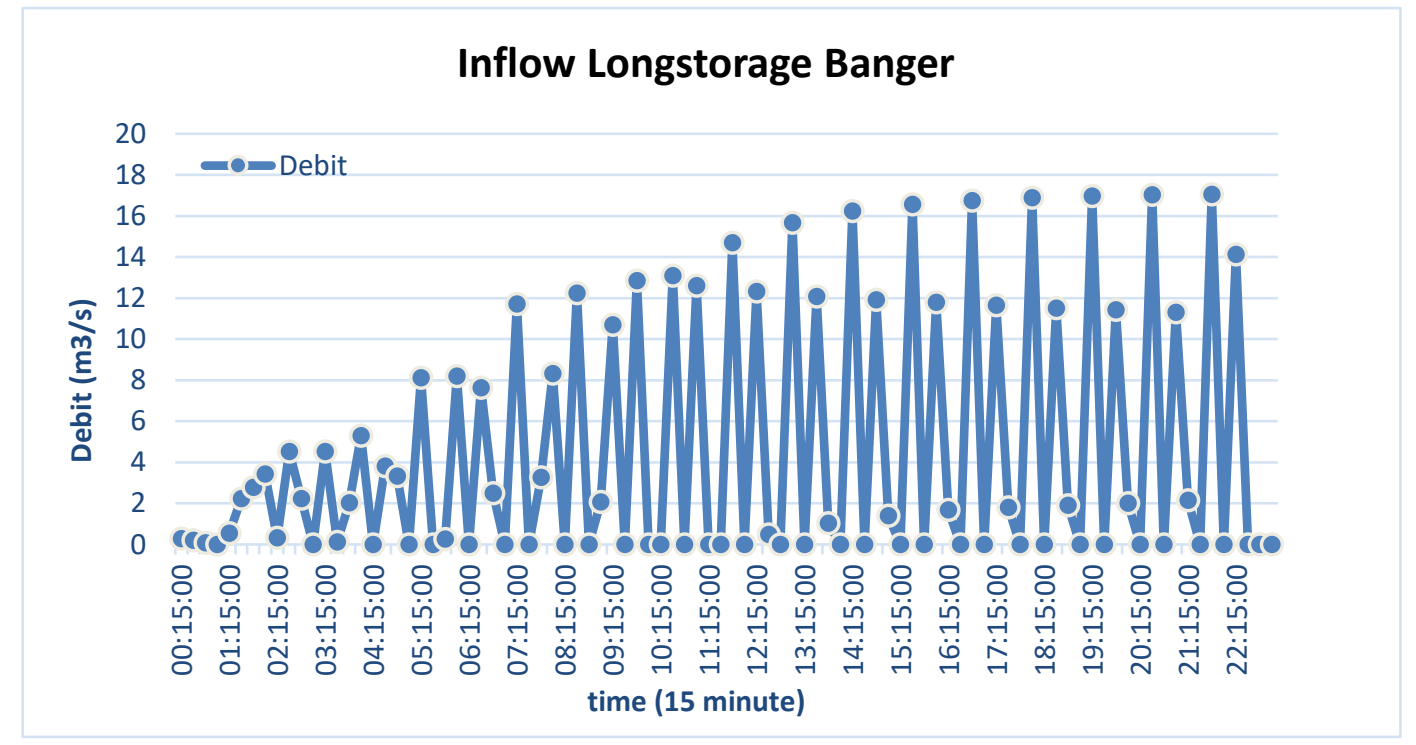

Figure 5 Inflow Longstorage Banger

Table 6 Pump Operation Schedule

\begin{tabular}{|c|c|c|}
\hline $\begin{array}{c}\text { Water depth } \\
(\mathbf{m})\end{array}$ & $\begin{array}{c}\text { Elevation } \\
(\mathbf{m})\end{array}$ & $\begin{array}{c}\text { Pump debit } \\
\left(\mathbf{m}^{\mathbf{3}} \mathbf{\mathbf { d }}\right)\end{array}$ \\
\hline 0 & -4.7 & 0 \\
\hline 0.5 & -4.2 & 2 \\
\hline 1 & -3.7 & 2 \\
\hline 1.5 & -3.2 & 2 \\
\hline 2 & -2.7 & 2 \\
\hline
\end{tabular}


The following is the condition of Longstorage Banger water level fluctuation when the pump is operated. In Figure 6 it can be seen that the pool water level can be maintained at a depth of $2.3 \mathrm{~m}$ and does not overflow

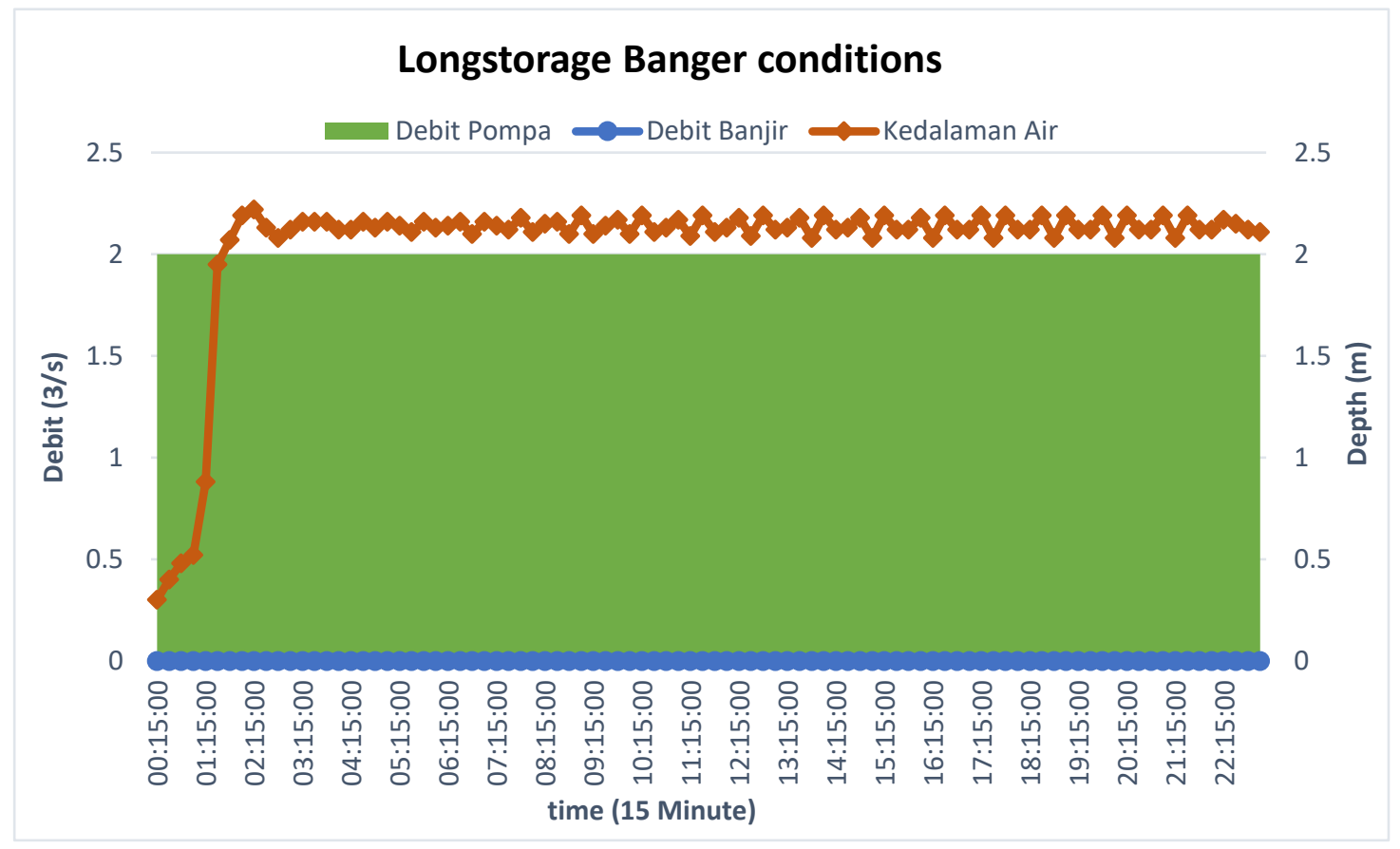

Figure 6 Banger Longstorage Depth Conditions

The banger watershed control model is carried out by considering the size of the aria cacthment, while also considering the existing conditions so that in the flood control model in the watershed, With a retention pond area of $13.54 \mathrm{ha}$, pool depth of $3.0 \mathrm{~m}$ and a reservoir volume of $406,000 \mathrm{~m}^{3}$. pump capacity of $5 \mathrm{~m}^{3} / \mathrm{s}$, research conducted according to Lina Damayanti (2017). With Semarang Indah's long storage it is designed using 5 pumps with a capacity of $3 \mathrm{~m}^{3} / \mathrm{s}$ and 2 existing pumps with a capacity of $0.6 \mathrm{~m}^{3} / \mathrm{s}$, the long storage location in Madukoro is designed using 3 pumps with a capacity of $1.2 \mathrm{~m}^{3} / \mathrm{s}$ and 2 existing pumps with a capacity of $0.6 \mathrm{~m}^{3} / \mathrm{s}$, and Tawang Sari's long storage is designed using 4 pumps with a capacity of $1.5 \mathrm{~m}^{3} / \mathrm{s}$. This is in line with Royna Kristian Yudi (2017) The retention pond has an area of 126 hectares with a depth of 3.4 meters of ponds and a 10 year annual flood discharge plan for the pond is $126.6 \mathrm{~m}^{3} / \mathrm{s}$. There are 4 pumps with a capacity of $15 \mathrm{~m}^{3} / \mathrm{s}$ each. Discharge for each river is $82.3 \mathrm{~m}^{3} \mathrm{~s}$

\section{CONCLUSIONS}

The polder system is the most appropriate treatment for tidal flood control in the Banger watershed, with the concept of isolating sea water flow and controlling water elevation with pumps, channels, ponds, embankments :

- The Catchment area (CA) of the Banger River Basin is only affected by the distribution of rain recorded at the Tanjung Mas Maritime Rain Observing Station in Semarang. With an area of CA equal to the area of the Banger watershed that is 567,521 ha. Based on the recording of the depth of rain in the Maritime Sta, and after analyzing the rain area with the Thiessen method, a planned rainfall with a return period of 50 years is $182 \mathrm{~mm}$, which has been statistically tested with the distribution of the Pearson III log distribution. 
- With a retention pond area of 13.54 ha, the pool depth is $3.0 \mathrm{~m}$ and the storage volume is $406,000 \mathrm{~m}^{3}$. pump capacity of $5 \mathrm{~m}^{3} / \mathrm{s}$ The pump is set to start at a depth of 2.5 meters, and shut down at a depth of 0.5 meters. Pump capacity variations $3 \times 1.5 \mathrm{~m}^{3} / \mathrm{s}$ and $1 \times 0.5 \mathrm{~m}^{3} \mathrm{~s}$

\section{REFERENCES}

[1] Lina Dwi Damayanti, Hane Syafarini, Suseno Darsono *) S. Perencanaan Sistem Drainase Wilayah Tawang Sari Dan Tawang Mas Semarang Barat. Halaman [Internet]. 2017;6(2):194-203. Available from: http://ejournal-s1.undip.ac.id/index.php/jkts

[2] Suliyati T. Penataan Drainase Perkotaan Berbasis Budaya. 2014;19(1).

[3] Wahyudi SI. Tingkat Pengaruh Elevasi Pasang Laut Terhadap Banjir dan Rob di Kawasan Kaligawe Semarang. Riptek. 2007;1(1):27-34.

[4] Ismanto A, Wirasatriya A, Helmi M, Hartoko A. Model Sebaran Penurunan Tanah di Wilayah Pesisir Semarang. Ilmu Kelaut [Internet]. 2009;14(4):189-96. Available from: https://ejournal.undip.ac.id/index.php/ijms/article/viewFile/1622/1385

[5] Pratikso A, Sudarno S. Soil consolidation analysis as the main cause of land subsidence in Semarang - Indonesia. Int J Civ Eng Technol. 2019;10(2):793-802.

[6] Marfai MA, King L. Monitoring land subsidence in Semarang, Indonesia. Environ Geol. 2007;53(3):651-9.

[7] Suripin S, Kurniani D. Pengaruh Perubahan Iklim terhadap Hidrograf Banjir di Kanal Banjir Timur Kota Semarang. Media Komun Tek Sipil. 2016;22(2):119.

[8] Marfai MA, Cahyadi A, Anggraini DF. Tipologi, dinamika, dan potensi bencana di pesisir kawasan karst kabupaten gunungkidul. 27(2):147-58.

[9] Wahyudi SI, Faiqun M, Bras G Le. Problems, Causes and Handling Analysis of Tidal Flood, Erosion and Sedimentation in Northern Coast of Central Java: Review and Recommendation. 2012;(04):65-9.

[10] Karya J, Sipil T, Sistem P, Wilayah P, Timur S. 33 3. 2017;6:265-75. 